\title{
Gondrevile - Fontenoy-sur-Moselle
}

Au-dessus du Pralot - Croix Sainte-Anne

\section{Gilles Mangin}

\section{(2) OpenEdition \\ Journals}

Édition électronique

URL : http://journals.openedition.org/adlfi/8737

ISSN : 2114-0502

Éditeur

Ministère de la culture

Référence électronique

Gilles Mangin, "Gondrevile - Fontenoy-sur-Moselle », ADLFI. Archéologie de la France - Informations [En ligne], Lorraine, mis en ligne le 01 mars 2001, consulté le 19 avril 2019. URL : http:// journals.openedition.org/adlfi/8737

Ce document a été généré automatiquement le 19 avril 2019

(C) Ministère de la Culture et de la Communication, CNRS 


\title{
Gondrevile - Fontenoy-sur-Moselle
}

\author{
Au-dessus du Pralot - Croix Sainte-Anne
}

\section{Gilles Mangin}

Identifiant de l'opération archéologique : F1354200100016

Date de l'opération : 2001 (EV)

1 Les sondages, effectués préalablement à la réalisation d'une station d'épuration à Fontenoy-sur-Moselle $\left(7500 \mathrm{~m}^{2}\right)$ et d'une zone d'habitat à Gondreville $\left(12000 \mathrm{~m}^{2}\right)$, ont nécessité une petite opération d'évaluation, en raison de la sensibilité archéologique particulière de ce secteur. À Fontenoy-sur-Moselle, deux sondages ont livré des indices de site, avec sur l'un la présence de deux trous de poteau, vraisemblablement d'époque protohistorique, et dans le second la mise au jour d'un silo à grain. Ceux-ci se trouvent en vis-à-vis du site archéologique de la ZAC de Gondreville (voir Bilan scientifique régional 1996, p. 23-27). Une intervention archéologique devrait compléter ce diagnostic.

\section{INDEX}

Thèmes : silo, trou de poteau

Index chronologique : Protohistoire

Index géographique : Lorraine, Meurthe-et-Moselle (54), Gondreville

operation Fouille d'évaluation (EV) 


\section{AUTEUR}

\section{GILLES MANGIN}

AFAN 